Research paper

\title{
Evaluation of the stereoselectivity for titanium(IV)-based coordination entities induced by the enantiopure diphenylethene-1,2-diamine ligand
}

\author{
Emilie Macker ${ }^{\mathrm{a}}$, Laurent Barloy ${ }^{\mathrm{a}}$, Alain Chaumont ${ }^{\mathrm{a}}$, Nathalie Kyritsakas ${ }^{\mathrm{b}}$, Bruno Vincent ${ }^{\mathrm{c}}$, \\ Marc Henry ${ }^{\mathrm{a}}$, Pierre Mobian ${ }^{\mathrm{a}, *}$ \\ ${ }^{a}$ Laboratoire de Chimie Moléculaire de l'Etat Solide, UMR 7140 UDS-CNRS, Université de Strasbourg, 4 rue Blaise Pascal, F-67000 Strasbourg, France \\ ${ }^{\mathrm{b}}$ Laboratoire de Tectonique Moléculaire, UMR 7140 UDS-CNRS, Université de Strasbourg, 4 rue Blaise Pascal, F-67000 Strasbourg, France \\ ${ }^{\mathrm{c}}$ Service de RMN, Fédération de chimie Le Bel - FR2010, BP 296R8, 1, rue Blaise Pascal, F-67008 Strasbourg Cedex, France
}

\section{A R T I C L E I N F O}

\section{Keywords:}

Chirality

Helicates

$\mathrm{TiO}_{4} \mathrm{~N}_{2}$

Diphenylethene-1

2-Diamine

DFT

\begin{abstract}
A B S T R A C T
This article describes the formation of neutral $\mathrm{TiO}_{4} \mathrm{~N}_{2}$-based coordination entities where the titanium centers are coordinated by oxygenated ligands incorporating one or two biphenolato units, i.e. $\mathrm{L}^{1}$ and $\mathrm{L}^{2}$ respectively. In these systems, the sixfold coordination spheres of each metallic center are completed by the enantiopure bidentate diphenylethene-1,2-diamine compound, abbreviated as dpeda. A solvent dependent diastereomeric ratio is evaluated by ${ }^{1} \mathrm{H}$ NMR for the monomeric $\left[\operatorname{Ti}\left(\mathrm{L}^{1}\right)_{2}\left((1 R, 2 R)\right.\right.$-dpeda)] or $\left[\mathrm{Ti}\left(\mathrm{L}^{1}\right)_{2}((1 S, 2 S)\right.$-dpeda)] (abbreviated as [R-Ti] or $\left[S\right.$-Ti] respectively) complexes. The highest diastereomeric ratio for $\left[\mathrm{Ti}\left(\mathrm{L}^{1}\right)_{2}(\mathrm{dpeda})\right]$ is obtained in chloroform $(2: 1)$. Energy calculation and circular dichroism spectra simulation, obtained by DFT, permit to assign the configuration of the stereoisomer formed in excess. The $(1 R, 2 R)-(+)$-dpeda privileges the $\Delta$ form and $(1 S, 2 S)-(-)$-dpeda the $\Lambda$ form of the $\left[\mathrm{Ti}\left(\mathrm{L}^{1}\right)_{2}\right.$ (dpeda)] stereoisomers. The helicates formulated as $\left[\mathrm{Ti}_{2}\left(\mathrm{~L}^{2}\right)_{2}((1 S, 2 S) \text {-dpeda })_{2}\right]$ and $\left.\left[\mathrm{Ti}_{2}\left(\mathrm{~L}^{2}\right)_{2}(1 R, 2 R) \text {-dpeda }\right)_{2}\right]$ (abbreviated as [S-Ti2] or [R-Ti2] respectively) are obtained by following a multi-component self-assembly approach. In this case, the diastereomeric ratios evaluated by ${ }^{1} \mathrm{H}$ NMR are much lower compared to those determined for the monomeric species, and a privileged $P$ and $M$ configuration for the $\left.\left[\mathrm{Ti}_{2}\left(\mathrm{~L}^{2}\right)_{2}(1 R, 2 R) \text {-dpeda }\right)_{2}\right]$ helicate and the $\left[\mathrm{Ti}_{2}\left(\mathrm{~L}^{2}\right)_{2}((1 S, 2 S) \text {-dpeda })_{2}\right]$ helicate respectively is assigned through theoretical calculations. Overall, this article describes a strategy to favour handedness in a helicate system where the chiral control is originated from a ligand that is not inscribed within the helical framework of the architecture.
\end{abstract}

\section{Introduction}

The stereoselective synthesis of coordination compounds has become a very active field since several decades, owing to the major role played by chiral complexes in various domains such as catalysis, materials science and biological applications [1]. Focussing on chiral supramolecular polynuclear coordination compounds, the preparation of these architectures in a stereoselective fshion remains extremely challenging [2]. Helicates, which are the result of the spontaneous self-assembly process between metal ions and organic strands, are by definition chiral assemblies due to their inherent helicity $[3,4]$. Therefore, many efforts have been devoted to the development of strategies leading to scalemic mixtures of helicates [5]. The most frequent approach consists of the preparation of organic strands containing chiral information in the linker [6] or at the ligand termini [7] that generate optically pure or enriched helicates in the presence of metal ions. For charged helicates, the stereocontrol could also be originated by the presence of enantiopure counterions [8]. Another way to achieve the stereocontrol of metallo-supramolecular structures implies the coordination of chiral organic additives to coordination sites that do not participate in the construction of the helical framework of the molecule [9]. However, this strategy is much more confidential in the case of helicates [10], as most of the reported helicates contain metal ions where all the coordination sites are occupied by ligating atoms belonging to the organic strands conferring the helical structure of the complex.

Recently, our group has reported some examples of helicates built up around $\mathrm{TiO}_{4} \mathrm{~N}_{2}$ centers through a multicomponent self-assembly approach [11]. The components involved in these chiral systems are $\mathrm{Ti}$ (IV), achiral nitrogen bidentate ligands (ortho-phenylenediamine [11a] or 2,2-bipyrimidine [11b]) and a bis-biphenol pro-ligand where the two biphenol units are linked by a $p$-phenylene spacer (Fig. 1a) named as

\footnotetext{
* Corresponding author.

E-mail address: mobian@unistra.fr (P. Mobian).
} 
a)<smiles>Cc1cccc(-c2cccc(-c3ccccc3)c2O)c1O</smiles>

$$
\begin{aligned}
& \mathrm{n}=0, \mathrm{~L}^{1} \mathrm{H}_{2} \\
& \mathrm{n}=1, \mathrm{~L}^{2} \mathrm{H}_{4}
\end{aligned}
$$

b)<smiles>NC(c1ccccc1)[C@H](N)c1ccccc1</smiles><smiles>NC(c1ccccc1)[C@@H](N)c1ccccc1</smiles>

$(1 \mathrm{R}, 2 \mathrm{R})-(+)$

(1S, 2S)-(-)
Fig. 1. Ligands involved in this study. a) Pro-ligands $\mathrm{L}^{1} \mathrm{H}_{2}$ and $\mathrm{L}^{2} \mathrm{H}_{4}$. b) Both enantiomers of the diphenylethene-1,2-diamine (dpeda).

$\mathrm{L}^{2} \mathrm{H}_{4}$. All these architectures display the same three sources of chirality: a $P$ or $M$ chirality linked to their helical structure, a $\Delta$ or $\Lambda$ chirality found at each metallo-vertex and a $a S$ or $a R$ axial chirality provided by the non-planarity of two consecutive phenolato-units.

Herein, we investigate the influence of a chiral diamino ligand on the overall chirality of the resulting Ti(IV)-based complexes incorporating $\mathrm{L}^{1}$ or $\mathrm{L}^{2}$. The chiral bidendate nitrogen ligand selected for the present study is the widely used $(+)$ or $(-)$ diphenylethene-1,2diamine compound, abbreviated as dpeda (Fig. 1b) [12]. Firstly, the formation of a monomeric $\mathrm{TiO}_{4} \mathrm{~N}_{2}$ complex formed with two substituted 2,2'-biphenolato ligands ( $\mathrm{L}^{1}$ ) (Fig. 1a) and a chiral nitrogen ligand is detailed. Next, this coordination chemistry is extended to the formation of a dinuclear helicate incorporating two $\mathrm{TiO}_{4} \mathrm{~N}_{2}$ units.

\section{Results and discussion}

\subsection{Monomeric $\left[\mathrm{Ti}\left(L^{1}\right)_{2}(\right.$ dpeda $\left.)\right]$ complexes}

A family of monomeric octahedral complexes bearing various bidentate nitrogen ligands and two $\mathrm{L}^{1}$ ligands has been previously reported [13]. These species constructed around a $\mathrm{TiO}_{4} \mathrm{~N}_{2}$ core are obtained by reacting the $\left[\mathrm{Ti}\left(\mathrm{L}^{1}\right)_{2}\left(\mathrm{HOPr}^{\mathrm{i}}\right)_{2}\right]$ precursor with a nitrogen ligand via ligand exchange. By following a similar procedure, the desired $\left[\mathrm{Ti}\left(\mathrm{L}^{1}\right)_{2}\right.$ (dpeda)] complexes are synthesized as described in Eq. (1) with both dpeda enantiomers.

$\left[\operatorname{Ti}\left(\mathrm{L}^{1}\right)_{2}\left(\operatorname{HOPr}^{\mathrm{i}}\right)_{2}\right]+$ dpeda $\rightarrow\left[\operatorname{Ti}\left(\mathrm{L}^{1}\right)_{2}(\right.$ dpeda $\left.)\right]+2 \mathrm{HOPr}^{\mathrm{i}}$

The $\left[\mathrm{Ti}\left(\mathrm{L}^{1}\right)_{2}((1 R, 2 R)\right.$-dpeda)] (abbreviated as $[R$-Ti]) or $[\mathrm{Ti}$ $\left(\mathrm{L}^{1}\right)_{2}((1 S, 2 S)$-dpeda)] (abbreviated as [S-Ti]) complex crystallizes directly from the reaction solution when vapours of $n$-pentane are used as counter-solvent. The red crystalline solids are isolated by filtration and analysed. The ${ }^{1} \mathrm{H}$ NMR spectrum of the $\left[\mathrm{Ti}\left(\mathrm{L}^{1}\right)_{2}((1 R, 2 R)\right.$-dpeda) $)$ crystals dissolved in $\mathrm{CD}_{2} \mathrm{Cl}_{2}$ is rather complex in the aromatic region. We checked that an identical spectrum is obtained when the [S-Ti] complex is analysed. Each spectrum exhibits two sets of signals in a $1.5: 1$ ratio. This ratio depends on the solvent employed to run the NMR experiment. These ratios determined for various solvents are gathered in Table 1. The higher ratio is gained when the spectrum of this complex is recorded in $\mathrm{CDCl}_{3}$. Nevertheless, it is difficult to rationalize the correlation between the diastereomeric ratio and the nature of the solvent.

As mentioned above, the aromatic region of the $\left[\mathrm{Ti}\left(\mathrm{L}^{1}\right)_{2}\right.$ (dpeda)]
Table 1

Diastereomeric ratios determined by ${ }^{1} \mathrm{H}$ NMR. Crystals of the $\left[\mathrm{Ti}\left(\mathrm{L}^{1}\right)_{2}\right.$ (dpeda)] or $\left[\mathrm{Ti}_{2}\left(\mathrm{~L}^{2}\right)_{2}(\mathrm{dpeda})_{2}\right]$ complexes obtained with an enantiopure dpeda ligand are dissolved in a deuterated solvent. For $\left[\mathrm{Ti}\left(\mathrm{L}^{1}\right)_{2}(\mathrm{dpeda})\right]$, the ratios are calculated from the integrals of the two doublets between $5.60 \mathrm{ppm}$ and $6.40 \mathrm{ppm}$ (see ESI). For $\left[\mathrm{Ti}_{2}\left(\mathrm{~L}^{2}\right)_{2}(\mathrm{dpeda})_{2}\right]$ the ratios are calculated from the integrals of the two singlets between $8.36 \mathrm{ppm}$ and $8.55 \mathrm{ppm}$. ${ }^{\text {a }}$ For the experiment run in $\mathrm{C}_{2} \mathrm{D}_{2} \mathrm{Cl}_{4}$, the signals between $1.80 \mathrm{ppm}$ and $3.40 \mathrm{ppm}$ are integrated. ${ }^{\mathrm{b}}$ The spectrum of $\left.\left[\mathrm{Ti}_{2}\left(\mathrm{~L}^{2}\right)_{2} \text { (dpeda) }\right)_{2}\right]$ in $\mathrm{CD}_{3} \mathrm{CN}$ was not recorded due to the poor solubility of the complex in this solvent.

\begin{tabular}{lll}
\hline \multirow{2}{*}{ Solvent } & \multicolumn{2}{l}{ diastereomeric ratio } \\
\cline { 2 - 3 } & {$\left[\mathrm{Ti}\left(\mathrm{L}^{1}\right)_{2}\right.$ (dpeda) $]$} & {$\left[\mathrm{Ti}_{2}\left(\mathrm{~L}^{2}\right)_{2}(\text { dpeda })_{2}\right]$} \\
\hline $\mathrm{CD}_{2} \mathrm{Cl}_{2}$ & $1.5: 1$ & $1: 1$ \\
${\text { Acetone- } d_{6}}_{\mathrm{CD}_{3} \mathrm{CN}^{\mathrm{b}}}$ & $1.7: 1$ & $1.2: 1$ \\
$\mathrm{C}_{2} \mathrm{D}_{2} \mathrm{Cl}_{4}{ }^{\text {a }}$ & $1.8: 1$ & - \\
$\mathrm{CDCl}_{3}$ & $1.95: 1$ & $1: 1$ \\
\hline
\end{tabular}

spectrum in $\mathrm{CD}_{2} \mathrm{Cl}_{2}$ is complex, but the assignment of several signals between $1.8 \mathrm{ppm}$ and $4 \mathrm{ppm}$ is possible through COSY, HMBC, HSQC and ROESY experiments. This region displays two sets of three signals attributed to the $\mathrm{N}_{2}$ and $\mathrm{CH}$ resonances of the dpeda ligand (see ESI). DOSY measurement highlights only one diffusion in $\mathrm{CDCl}_{3}$ for these two species with a diffusion coefficient of $580 \pm 10 \% \mu \mathrm{m}^{2} . \mathrm{s}^{-1}$ which corresponds, according to the Stokes-Einstein equation, to a hydrodynamic radius of $R_{\mathrm{h}}=7.0 \pm 0.7 \AA$. This value matches the size of a monomeric complex [13]. Additionally, ES-MS analysis displays an intense peak at $m / z=933.32$ corresponding to the mass of the [[Ti $\left(\mathrm{L}^{1}\right)_{2}((1 R, 2 R)$-dpeda) $\left.]+\mathrm{H}\right]^{+}$ion (see ESI).

Altogether, these data are conclusive with the presence in solution of two diastereoisomers in different proportions when the crystalline solid of $\left[\mathrm{Ti}\left(\mathrm{L}^{1}\right)_{2}((1 R, 2 R)\right.$-dpeda $\left.)\right]$ or $\left[\mathrm{Ti}\left(\mathrm{L}^{1}\right)_{2}((1 S, 2 S)\right.$-dpeda $\left.)\right]$ is dissolved. For the complexes formed with $(1 R, 2 R)$-dpeda, these diastereoisomers are assigned to $\Delta$-[R-Ti] and $\Lambda$-[R-Ti]. Optimised structures of $\Delta$-[R-Ti] and $\Lambda$-[R-Ti] complexes, computed via density functional theory (DFT) using the long range corrected wB97XD functional [14], are shown in Fig. 2. These modelled structures were obtained starting from a $\mathrm{Ti}\left(\mathrm{L}^{1}\right)_{2}$ motif, extracted from the crystal structure of a $\mathrm{TiO}_{4} \mathrm{~N}_{2}$ based monomeric complex [13], for which the dpeda ligand has been implemented.

As far as previous monomeric titanium complexes built around a $\mathrm{TiO}_{4} \mathrm{~N}_{2}$ core usually show dynamic behavior [13], the same behaviour is expected for these complexes incorporating the enantiopure dpeda ligand. The ${ }^{1} \mathrm{H}$ NMR spectrum of $\left[\mathrm{Ti}\left(\mathrm{L}^{1}\right)_{2}((1 R, 2 R)\right.$-dpeda) $]$ in $\mathrm{C}_{2} \mathrm{D}_{2} \mathrm{Cl}_{4}$ was recorded at variable temperature from $293 \mathrm{~K}$ to $371 \mathrm{~K}$ (Fig. 3). The coalescence of several signals was observed and attributed to a $\Delta \leftrightarrows \Lambda$ inversion of configuration. In particular, the evolution of the signals at $\delta=5.02$ and $5.57 \mathrm{ppm}$ assigned to the ortho protons of the dpeda ligand is followed (Fig. 3a). Despite the presence of signals of the solvent a)

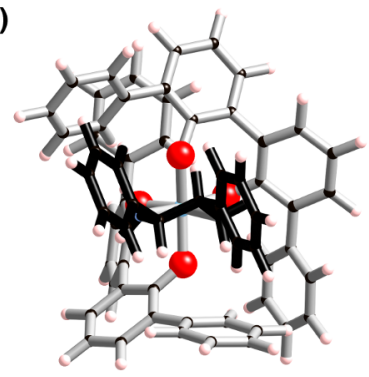

b)

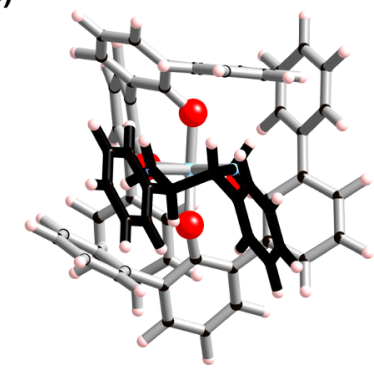

Fig. 2. a) Computed molecular models of $\Lambda$-[R-Ti]. b) Computed molecular models of $\Delta$-[R-Ti]. The computed models of $\Lambda$-[Ti( $\left(\mathrm{L}^{1}\right)_{2}((1 S, 2 S)$-dpeda) $]$ and $\Delta$ $\left[\mathrm{Ti}\left(\mathrm{L}^{1}\right)_{2}\left((1 S, 2 S)\right.\right.$-dpeda)] are given in ESI. $\mathrm{L}^{1}$ are in grey, dpeda in black, Ti in blue and $\mathrm{O}$ in red. 
a)

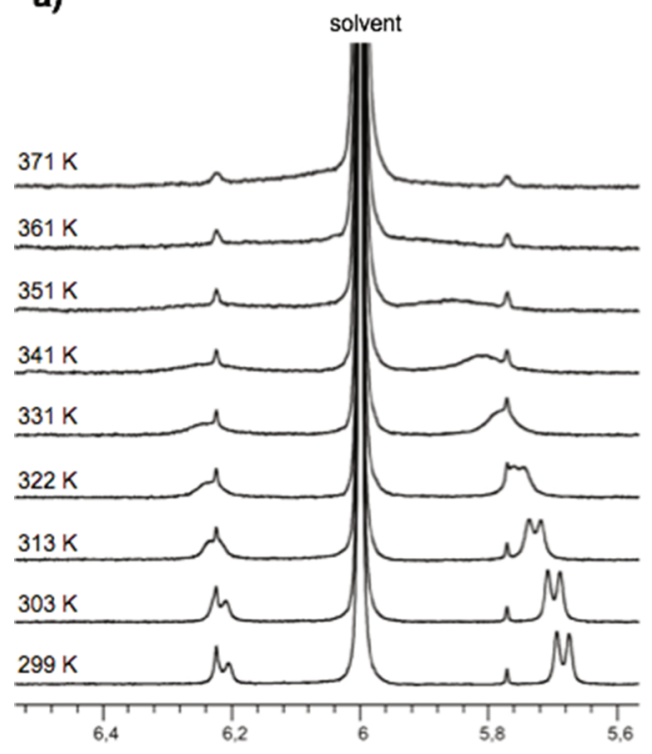

b)

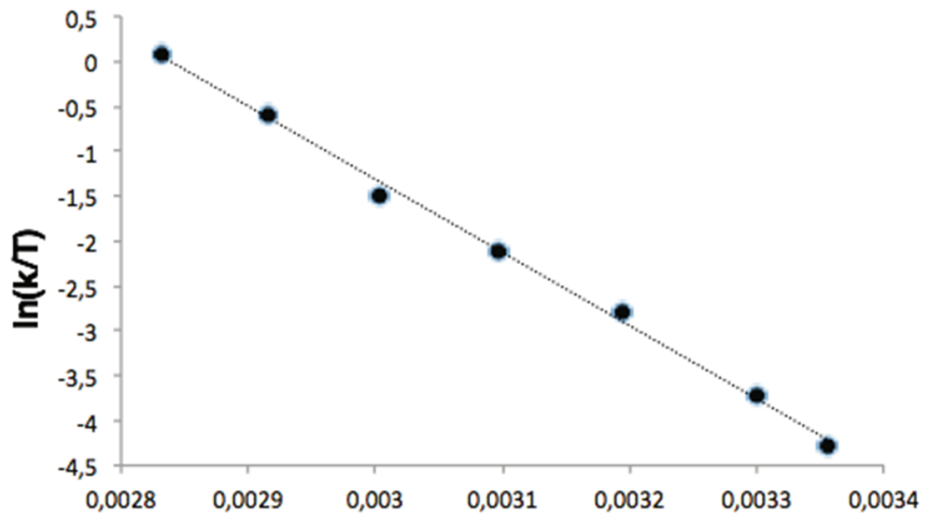

$1 / T$

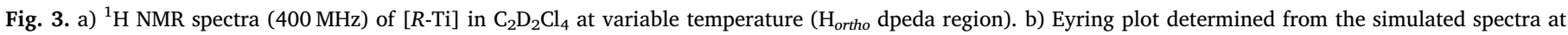
variable temperature of $[R-\mathrm{Ti}]\left(\mathrm{H}_{\text {ortho }}\right.$ dpeda region). The estimated error for each $\ln (\mathrm{k} / \mathrm{T})$ value is $\pm 5 \%$.

${ }^{13} \mathrm{C}$ satellites superimposed with the studied signals, it is possible to simulate these signals and to extract the kinetic constants. The Eyring plot (Fig. 3b) allows us to determine the activation parameters, $\Delta \mathrm{H}^{\neq}$, $\Delta S^{\neq}$and $\Delta \mathrm{G}^{\neq}$associated to this fluxional process. $\Delta \mathrm{H}^{\neq}$and $\Delta \mathrm{S}^{\neq}$are respectively found to be $67.8 \pm 4 \mathrm{~kJ} \cdot \mathrm{mol}^{-1}$ and $192.4 \pm 10 \mathrm{~J} \cdot \mathrm{mol}^{-1} \cdot \mathrm{K}^{-1}$. The positive $\Delta S^{\neq}$value suggests a process involving a weakly constrained transition state, whereas the rather high enthalpy suggests an elongation of the $\mathrm{Ti}-\mathrm{N}$ bonds for the transition state.

Next, chiroptical properties of these two complexes [S-Ti] and $[R$ Ti] are studied by electronic circular dichroism (ECD) as shown in Fig. 4. The analysed solutions are prepared by dissolving [S-Ti] crystals or $[R-\mathrm{Ti}]$ crystals in dichloromethane. In the visible region, in which the free enantiopure dpeda molecule is CD-silent, i.e. above $280 \mathrm{~nm}$, the ECD spectra are mirror-image in the $400-500 \mathrm{~nm}$ region. It should be mentioned that the absorption in the visible domain for phenolatobased titanium(IV) complexes is due to charge transfers between the lone pair of the oxygen atoms and the empty 3d-orbitals of the Ti(IV) [15]. The UV-visible absorption spectrum of [S-Ti] given in ESI

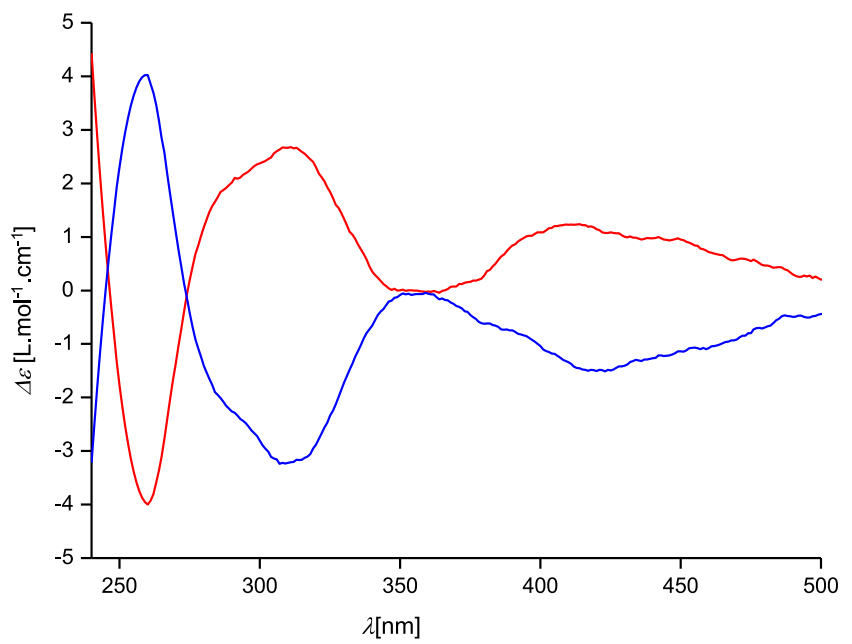

Fig. 4. CD-spectra of [S-Ti] (blue curve) and [R-Ti] (red curve) (RT, $\mathrm{CH}_{2} \mathrm{Cl}_{2}$, $10^{-5}$ mol. $\mathrm{L}^{-1}$ ). confirms the presence of a broad band $\left(\varepsilon_{430}=2280 \mathrm{~L} \cdot \mathrm{mol}^{-1} . \mathrm{cm}^{-1}\right)$ between $400 \mathrm{~nm}$ and $500 \mathrm{~nm}$. Next, at $310 \mathrm{~nm}$, positive and negative peaks are observed for $[R-\mathrm{Ti}]$ and $[S$-Ti] respectively. Also, for the region where the $(-)$ and $(+)$ dpeda enantiomers are active, two symmetrical curves are observed. Undoubtedly, these chiroptical properties of the analysed complexes confirm the excess of one diastereoisomer compared to the other as highlighted by ${ }^{1} \mathrm{H}$ NMR analysis.

\section{2. $\left[\mathrm{Ti}_{2}\left(L^{2}\right)_{2}((1 S, 2 S)-d p e d a)_{2}\right]$ and $\left[\mathrm{Ti}_{2}\left(L^{2}\right)_{2}((1 R, 2 R)-\text { dpeda })_{2}\right]$ helicates}

For the synthesis of the dimeric complexes incorporating the $\mathrm{L}^{2}$ ligand instead of $\mathrm{L}^{1}$, the synthetic methodology is different from the one described above, as the multicomponent self-assembly process described in Eq. (2) is performed in warm toluene $\left(100^{\circ} \mathrm{C}\right)$ starting from $\mathrm{L}^{2} \mathrm{H}_{4},(+)$ or (-)-dpeda and $\mathrm{Ti}\left(\mathrm{O}^{\mathrm{i}} \mathrm{Pr}\right)_{4}$.

$\mathrm{L}^{2} \mathrm{H}_{4}+2 \mathrm{Ti}\left(\mathrm{O}^{\mathrm{i} P r}\right)_{4}+2$ dpeda $\rightarrow\left[\mathrm{Ti}_{2}\left(\mathrm{~L}^{2}\right)_{2}(\text { dpeda })_{2}\right]+8 \mathrm{HO}^{\mathrm{i}} \mathrm{Pr}$

Under these conditions, orange crystals appear in the medium after a few days. Single crystals are obtained by performing the reaction with either $(1 S, 2 S)$-(-)-dpeda or $(1 R, 2 R)-(+)$-dpeda. The crystal structures of $\left[\mathrm{Ti}_{2}\left(\mathrm{~L}^{2}\right)_{2}((1 S, 2 S) \text {-dpeda })_{2}\right]([S$-Ti2 $])$ and $\left[\mathrm{Ti}_{2}\left(\mathrm{~L}^{2}\right)_{2}((1 R, 2 R) \text {-dpeda })_{2}\right]$ $([R-T i 2])$ are displayed in Fig. 5 . These compounds crystallize in the centrosymmetric $P 2_{1}$ space group with four molecules per unit cell. These structures are very similar to the previously reported helicate built from the ortho-phenylenediamine ligand since two inequivalent $\mathrm{L}^{2}$ strands are found in these architectures with one $\mathrm{L}^{2}$ ligand wrapped around a second fully extended $\mathrm{L}^{2}$ strand [11a]. Several sources of chirality are found in these structures: a $P$ or $M$ helicity, a $\Delta$ or $\Lambda$ chirality provided by each octahedral metal centre, an aR or a $S$ axial chirality arising from the non-planarity of two consecutive phenolato units and also the presence of two stereogenic centers within the dpeda ligands. In these crystalline networks, two diastereoisomers characterized by an opposite helicity are found. For instance, concerning the helicate obtained with $(1 S, 2 S)-(-)$-dpeda, both $(P)$ - $[S$-Ti2] and $(M)$ - $[S$ Ti2] are observed in the unit cell in equal proportion with a $\Delta \Delta$ and a $\Lambda \Lambda$ configuration found at each metal center for the $P$ and $M$ helicate respectively. Concerning the metrical description of the complex, an intermetallic distance of $8.8 \AA$ separates the two titanium centres. The Ti$\mathrm{N}$ bonds are longer compared to the Ti-O bonds with mean Ti-N and Ti- 
a)

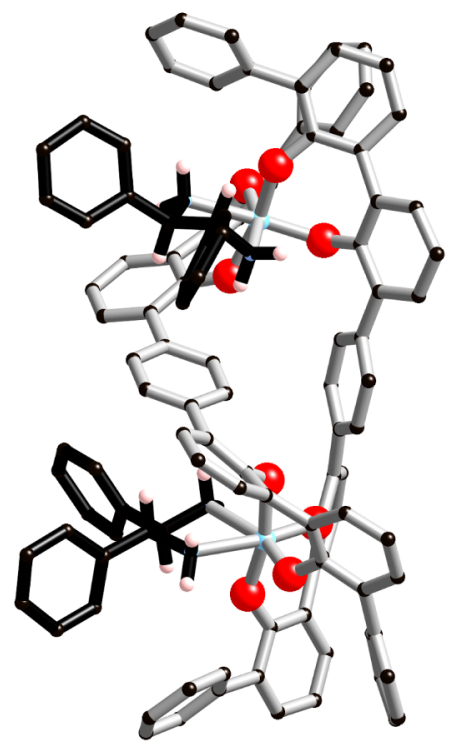

C)

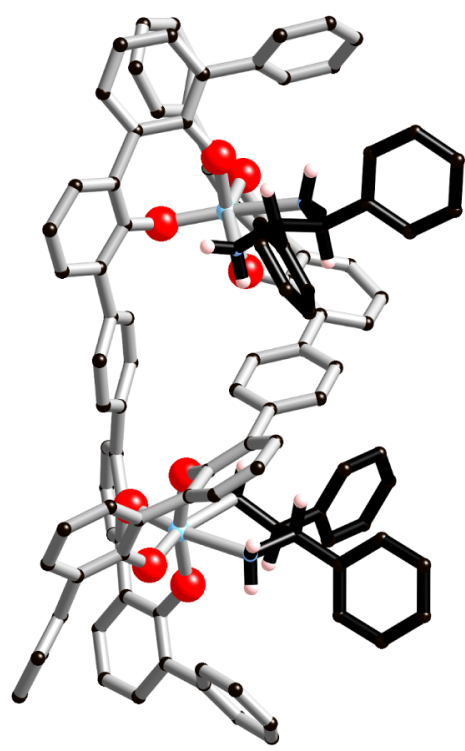

b)
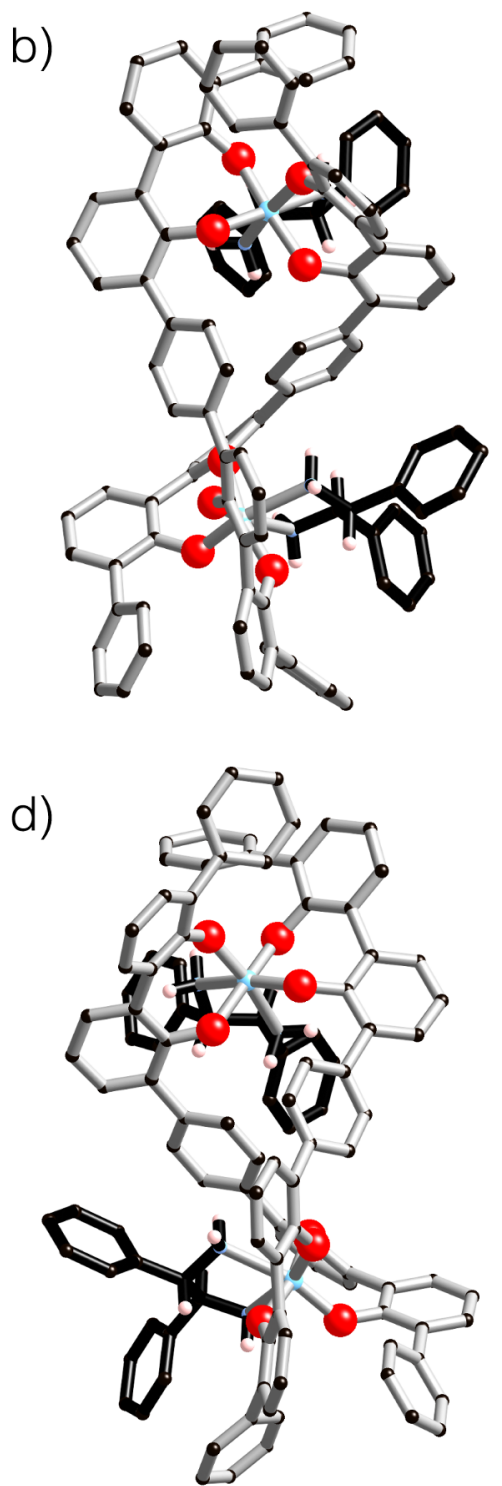

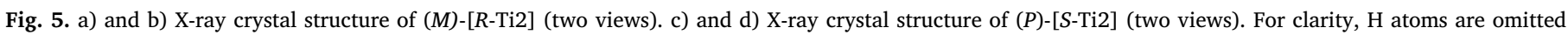
except for the non-aromatic hydrogens of the dpeda ligand. $\mathrm{L}^{2}$ are in grey, dpeda in black, Ti in blue and $\mathrm{O}$ in red.

O lengths found in [S-Ti2] of $2.239 \pm 0.057 \AA$ and $1.872 \pm 0.044 \AA$ respectively; these values lie in the usual range [11a]. Having established the structure of these species, the crystals were dissolved in a deuterated solvent and the resulting solutions were analysed by ${ }^{1} \mathrm{H}$ NMR. Again, the ${ }^{1} \mathrm{H}$ NMR spectrum is highly complex; nevertheless, two sets of signals in different ratio, depending on the solvent used to perform the NMR experiment, could be clearly identified. These ratios extracted for this series of spectra are listed in Table 1. In average, the ratios corresponding to the dimeric species are lower compared to those gained for $\left[\mathrm{Ti}\left(\mathrm{L}^{1}\right)_{2}\right.$ (dpeda)]. In $\mathrm{CD}_{2} \mathrm{Cl}_{2}$ and $\mathrm{C}_{2} \mathrm{D}_{2} \mathrm{Cl}_{4}$, the two species are present in a $1: 1$ ratio, whereas in acetone- $d_{6}$ a $1.2: 1$ ratio is noted.

According to DOSY, only one single diffusion coefficient is attributed to these species in $\mathrm{CDCl}_{3}$ at $\mathrm{D}=420 \pm 10 \% \mu \mathrm{m}^{2}$.s ${ }^{-1}$, which corresponds to an hydrodynamic radius of $9.6 \pm 0.9 \AA$ compatible with a dinuclear assembly. A single intense peak is detected by mass spectrometry analysis (ES-MS) at $m / z=1732.52$, matching the $\left[\mathrm{Ti}_{2}\left(\mathrm{~L}^{2}\right)_{2}((1 S, 2 S) \text {-dpeda })_{2}+\mathrm{Na}\right]^{+}$ion. As for the monomeric complexes, the presence in solution of two diasteroisomers upon crystal dissolution is confirmed by these investigations. Two dimensional NMR experiments (COSY, ROESY, HSQC) allowed us to assign a majority of the signals. This assignment is proposed in the ESI. In particular, the ${ }^{1} \mathrm{H}$ NMR spectrum shows the six characteristic signals above $7.94 \mathrm{ppm}$ attributed for each diastereoisomer to the protons of the para-phenylene bridges within the helicate. More precisely, for one diastereoisomer, the four protons of one para-phenylene bridge resonate as one sharp singlet, whereas two singlets integrating for two protons each correspond to the resonance of the rest of the para-phenylene protons within a helicate. This is in full accordance with an orthogonal arrangement of the two para-phenylene bridges within the complex, as observed in the $C_{2}$ symmetric crystal structure. Contrary to the monomeric species, no coalescence of the signals is observed when the complex is heated up to $371 \mathrm{~K}\left(\mathrm{C}_{2} \mathrm{D}_{2} \mathrm{Cl}_{4}\right)$. Furthermore, 2D ROESY analysis performed at room temperature reveals no cross peak due to chemical exchange. This reflects the high helical configuration stability for a diastereoisomer in the range of temperature studied. Due to the poor diastereomeric excess highlighted by NMR, we anticipated that the CD signal in the dpeda ligand silent region of the [S-Ti2] and [R-Ti2] complexes would be very weak. However, the solutions obtained by dissolving the [S-Ti2] and [R-Ti2] crystals in $\mathrm{CH}_{2} \mathrm{Cl}_{2}$ studied by circular dichroism display for the visible region, as for the $\left[\mathrm{Ti}\left(\mathrm{L}^{1}\right)_{2} \mathrm{dpeda}\right]$ complexes, mirror-image 


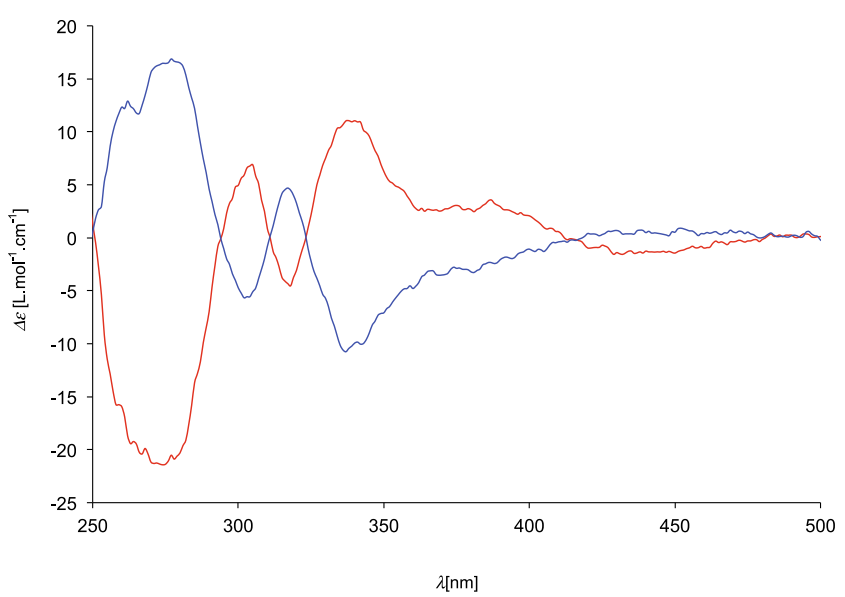

Fig. 6. CD-spectra of [S-Ti2] (blue curve) and [R-Ti2] (red curve) $\left(\mathrm{CH}_{2} \mathrm{Cl}_{2}\right.$, $10^{-5}$ mol. $\left.\mathrm{L}^{-1}\right)$.

signals for [R-Ti2] and [S-Ti2] respectively, which allows to anticipate significant chiroptical properties if an isolated stereoisomer is considered (Fig. 6). Importantly, when the crystal used to resolve the structure of $[R$-Ti2] by X-ray diffraction analysis is dissolved in dichloromethane and the resulting solution analysed by $C D$, a CD curve similar to the one recorded for the analysis of [R-Ti2] is obtained (see ESI). This clearly demonstrates that the $1: 1$ diastereomeric proportion of $(P)$ - $[R$-Ti2] and $(M)$-[R-Ti2] characterized in the crystal lattice is modified upon crystal dissolution due to different energies associated to each diastereoisomer despite the apparent equal diastereomeric proportion determined by ${ }^{1} \mathrm{H}$ NMR in $\mathrm{CD}_{2} \mathrm{Cl}_{2}$. Thus, the crystal packing forces could explain the equal diastereomeric proportion found in the crystalline state.

\subsection{Computational investigations}

The assignment of the chiroptical properties to the correct stereoisomer is indeed a major issue in the present study. In a similar manner, for the monomeric species as well as for the helicates, the identification of the most predominant diastereoisomer highlighted by the NMR spectra is also essential. Thus, the structures for all the possible stereoisomers of the $\left.\left[\mathrm{Ti}_{2}\left(\mathrm{~L}^{2}\right)_{2} \text { (dpeda }\right)_{2}\right]$ and $\left[\mathrm{Ti}^{1} \mathrm{~L}^{1}\right)_{2}$ (dpeda) $]$ complexes were modelled in the gas phase using density functional theory (DFT) with the long range corrected functional wB97XD. The computed molecular models of $(\Delta)$-[R-Ti] and $(\Lambda)$-[R-Ti] were already shown in Fig. 1 (the models of the two monomeric complexes incorporating the $(1 S, 2 S)-(-)$-dpeda are given in ESI). In ESI are also found the models of the four helicate stereoisomers, the computed structures of which were calculated starting from their crystal structures. The energy differences associated to a pair of diastereoisomer with opposite $\Delta / \Lambda$ or $P / M$ configuration are listed in Table 2.

For the monomeric complexes, a marked difference of energy is found between two diastereoisomers bearing the same enantiopure

Table 2

Results from DFT calculations. The energies are calculated for the complexes in gas phase.

\begin{tabular}{lll}
\hline & & wB97XD // Def2TZVP \\
\hline$[R$-Ti $]$ & $\Delta \mathrm{E}(\Lambda-\Delta)$ & $1.7 \mathrm{~kJ} / \mathrm{mol}$ \\
& ratio $(\Delta / \Lambda)$ & 2.00 \\
{$[S$-Ti $]$} & $\Delta \mathrm{E}(\Lambda-\Delta)$ & $-1.7 \mathrm{~kJ} / \mathrm{mol}$ \\
& ratio $(\Delta / \Lambda)$ & 0.5 \\
{$[R$-Ti2 $]$} & $\Delta \mathrm{E}(P-M)$ & $-0.4 \mathrm{~kJ} / \mathrm{mol}$ \\
& ratio $(P / M)$ & 1.16 \\
{$[S$-Ti2 $]$} & $\Delta \mathrm{E}(P-M)$ & $0.4 \mathrm{~kJ} / \mathrm{mol}$ \\
& ratio $(P / M)$ & 0.86 \\
\hline
\end{tabular}

dpeda ligand. Concerning complexes formed with the $(1 R, 2 R)$ ( + )-dpeda ligand, the complex showing a $\Delta$ configuration is most stable whereas the $(1 S, 2 S)-(-)$-dpeda ligand induces a better stability for the $\Lambda$ form, meaning that the most predominant species observed by NMR are $(\Delta)$ - $\left[R\right.$-Ti] and $(\Lambda)$ - $[S$-Ti $]$ respectively. If the $\left[\mathrm{Ti}\left(\mathrm{L}^{1}\right)_{2}((1 R, 2 R)\right.$-dpeda $\left.)\right]$ stereoisomers are considered, the Boltzmann distribution law allows to calculate a $\Delta / \Lambda$ ratio matching extremely well with the ratio experimentally determined by ${ }^{1} \mathrm{H}$ NMR when the analysis is performed in $\mathrm{CDCl}_{3}\left(\right.$ ratio $_{\text {(exp.) }}=2$ ). Also, for the helicates, an energy difference is found between two diastereoisomers with opposite helicity. However, this difference is less pronounced as the one determined for two monomeric diastereoisomers. The ratio between $(P)$ - and $(M)$ - $[R$-Ti2] is only 1.16 , reflecting that the $P$ complex is a slightly more stable species compared to $(M)$-[R-Ti2]. Again, a good match is found with the experimental value determined by ${ }^{1} \mathrm{H}$ NMR for the diastereomeric mixture obtained if the [S-Ti2] or [R-Ti2] crystals is dissolved in $\mathrm{CDCl}_{3}$ (ratio $_{(\text {exp.) }}=1.1$ ).

Next, to interpret the recorded CD spectra and to propose their assignments, the simulated $\mathrm{CD}$ spectra were generated using the tightbinding based simplified Tamm-Dancoff approximation (sTDA-xtb) developed by Grimme et al. [16] and starting from the computed structures discussed just above. Fig. 7 displays the resulting CD spectra for the monomeric Ti-complexes and the double-stranded helicates. Two mirror-image curves are observed, when the CD spectra of the two enantiomers of $\left[\mathrm{Ti}\left(\mathrm{L}^{1}\right)_{2}\right.$ (dpeda)] are compared. A similar observation is made for the CD spectra of two diastereoisomers such as $(\Delta)$-[S-Ti] and $(\Lambda)$ - $[S$-Ti] but these curves have different intensities. Clearly, these theoretical CD spectra highlight that the chiroptical response of a monomeric species depends almost only on its $\Delta$ or $\Lambda$ configuration and that the enantiopure dpeda ligand within the complex has only a very minor impact on the CD signal. The same conclusions arise from the analysis of the CD spectra computed for the helicates. Two enantiomers as well as two diastereoisomers with an opposite helicity have mirror image $\mathrm{CD}$, but the curves have different intensities for two diastereoisomers. Table 3 lists the maxima associated with their signs of the experimental and computed CD spectra of the stereoisomers for the helicates and the monomeric complexes. Indeed, a strict comparison between the experimental data and the computed ones is untrivial since an experimental spectrum results from a solution containing two diastereoisomers and the theoretical curves are calculated for a modelled compound in the gas phase.

First, Table 3 highlights, for the monomeric complexes, that the theoretical spectra display more maxima compared to the experimental ones. Nevertheless, some similarities emerge when two spectra are

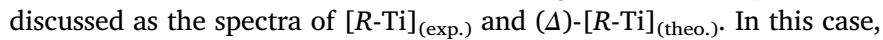
it appears that the two most intense CD signals for $\Delta-[R-T i]_{\text {(theo.) }}$, at $\lambda=293 \mathrm{~nm}(-)$ and $317 \mathrm{~nm}(+)$ respectively, possess identical signs as the two maxima found for $[R-\mathrm{Ti}]_{(\text {exp.) }}(\lambda=259 \mathrm{~nm} \mathrm{(-)}$ and $310 \mathrm{~nm}$ $(+)$ ). This similarity is limited to the UV region but it correlates that the $\Delta$ form is predicted to be the most stable diastereoisomer for [R-Ti]. A much better match in terms of wavelength accuracy and number of maxima is obtained for the helicates (see Table 3 , for instance entries $[R-\mathrm{Ti} 2]_{(\text {exp.) }}$ and $\left.(P)-[R-\mathrm{Ti} 2]_{(\text {theo.) }}\right)$. This confirms the previous assumptions gained via the energies calculation, as for the [R-Ti2] and [S-Ti2] assemblies, the $P$ and $M$ helicates are the most predominant species respectively.

\section{Conclusion}

Herein we investigated the stereoselective formation of monomeric and dinuclear complexes constructed around $\mathrm{TiO}_{4} \mathrm{~N}_{2}$ motifs by coordinating the enantiopure $(+)$ or $(-)$ diphenylethene-1,2-diamine ligand. More precisely, this study reported the case where the helicity of a titanium-based double-stranded helicate is influenced by a chiral information that is external to the helical framework of the architecture. Also, a solvent dependent effect on the diastereomeric ratio is noticed 
$\left[\operatorname{Ti}\left(\mathrm{L}^{1}\right)_{2}(\right.$ dpeda $\left.)\right]$

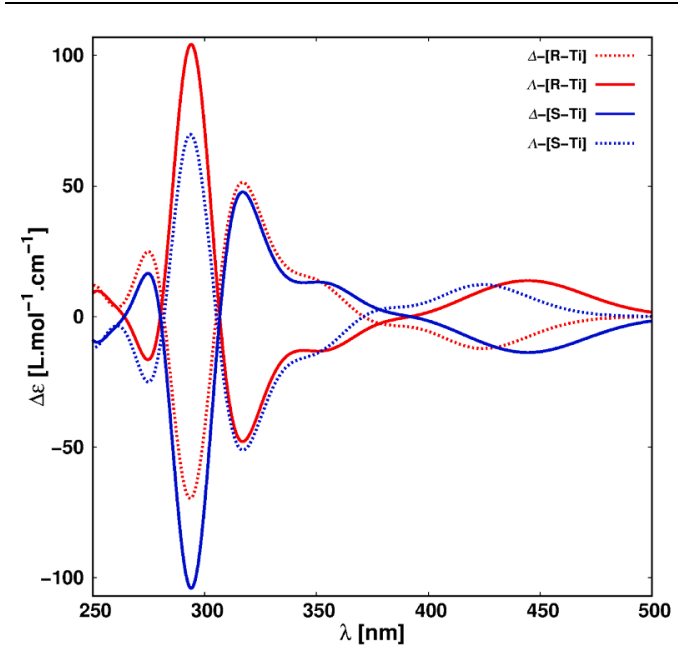

$\left[\mathrm{Ti}_{2}\left(\mathrm{~L}^{2}\right)_{2}(\mathrm{dpeda})_{2}\right]$

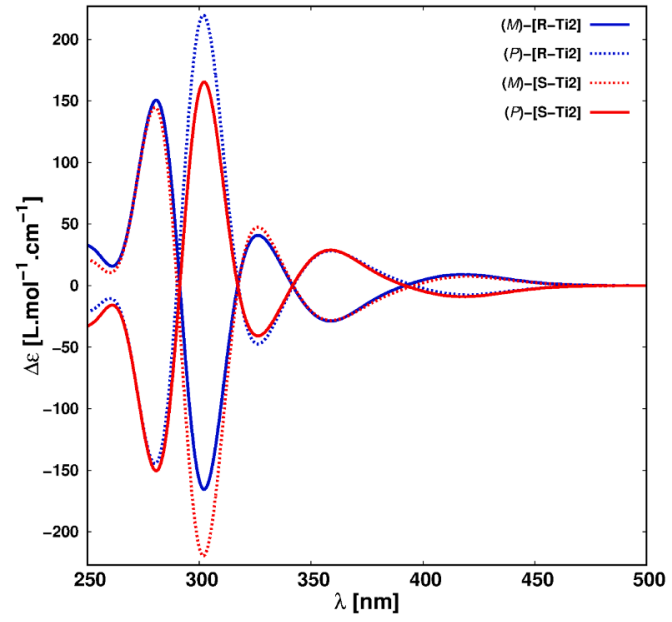

Fig. 7. Computed CD Spectra of the monomeric Ti-complexes (left) and Ti-helicates (right).

Table 3

Maxima of the experimental spectra compared to the theoretical spectra of selected stereoisomers. For clarity, only the theoretical data obtained for complexes incorporating the $(1 R, 2 R)-(+)$-dpeda ligands are listed (the corresponding enantiomers incorporating $(1 S, 2 S)$-(-)-dpeda have opposite signs).

\begin{tabular}{|c|c|c|c|c|c|c|}
\hline & & Waveleng & ths (nm) & & & \\
\hline \multirow[t]{4}{*}{ Experimental } & {$[R$-Ti $]$} & (-) 259 & (+) 310 & (+) 411 & & \\
\hline & {$[S$-Ti $]$} & (+) 259 & (-) 310 & (-) 420 & & \\
\hline & {$[S$-Ti2] } & (+) 277 & (-) 303 & (+) 317 & (-) 337 & $(+) 430$ \\
\hline & {$[R$-Ti2 $]$} & (-) 274 & (+) 305 & (-) 318 & (+) 338 & (-) 429 \\
\hline \multirow[t]{4}{*}{ Theoretical } & $\Delta-[R-\mathrm{Ti}]$ & (+) 251 & (+) 274 & (-) 293 & (+) 317 & (-) 424 \\
\hline & $\Lambda-[R-\mathrm{Ti}]$ & (-) 251 & (+) 275 & (-) 293 & (+) 317 & (-) 448 \\
\hline & $(M)-[R-T i 2]$ & (+) 280 & (-) 302 & (+) 325 & (-) 358 & $(+) 416$ \\
\hline & $(P)-[R-\mathrm{Ti} 2]$ & (-) 278 & (+) 299 & (-) 327 & (+) 358 & (-) 419 \\
\hline
\end{tabular}

for the $\left[\mathrm{Ti}\left(\mathrm{L}^{1}\right)_{2}\right.$ (dpeda) $]$ species and for the $\left[\mathrm{Ti}_{2}\left(\mathrm{~L}^{2}\right)_{2}(\mathrm{dpeda})_{2}\right]$ helicates. The energies calculation supported by simulated circular dichroism spectra allowed to determine that the $(1 R, 2 R)-(+)$-dpeda ligand induces preferentially the formation of the $\Delta$ and $P$ forms of [R-Ti] and $[R$-Ti2] respectively. In the case of the $(1 S, 2 S)-(-)$-dpeda ligand, an excess of the $(\Lambda)$ - $[S$-Ti] complex and of the $M$ helicate is generated. Overall, the diastereomeric ratios obtained with the dpeda ligand are rather modest, nevertheless it validates the initial goal of this study. These poor excesses are rationalized by the structural features of the $\mathrm{Ti}$ $\left(\mathrm{L}^{1}\right)_{2}$ and the $\mathrm{Ti}_{2}\left(\mathrm{~L}^{2}\right)_{2}$ sub-motifs providing no restricted environment to accommodate the dpeda ligands. Therefore, more sterically demanding chiral nitrogen ligands should increase the stereoselective control in these systems.

\section{Experimental section}

Bruker Avance-300, Avance-400 and Avance-500 were used for solution NMR spectroscopy analysis. 1H NMR DOSY measurements were performed at $600.13 \mathrm{MHz}$ with a $5 \mathrm{~mm} \mathrm{1H/X} \mathrm{z-gradient} \mathrm{BBI} \mathrm{probe}$ and by applying a PFGSTE pulse sequence using bipolar gradients. DOSY spectra were generated with the DOSY module of NMRNotebookTM software, through maximum entropy and inverse Laplace transform calculations. Mass spectrometry was performed at the Service Commun d'Analyses, Université de Strasbourg (France). The electrospray analyses were performed on Micro-TOF (Bruker) apparatus equipped with an electrospray (ES) source. CD spectra were recorded on a Jasco apparatus "J-810". A PerkinElmer polarimeter was used to mesure the optical rotation. The $(1 R, 2 R)-(+)$-dpeda $(98 \%)$ and $(1 S, 2 S)$ - (-)-dpeda (97\%) ligands were purchased from Alfa Aesar and $\mathrm{Ti}\left(\mathrm{O}^{\mathrm{i}} \mathrm{Pr}\right)_{4}$ (97\%) from Sigma-Aldrich. Complex $\left[\mathrm{Ti}\left(\mathrm{L}^{1}\right)_{2}\left(\mathrm{HOPr}^{\mathrm{i}}\right)_{2}\right]$ was synthesized following a reported procedure [17]. The X-ray diffraction data were collected at $173 \mathrm{~K}$ on a Bruker Smart CCD diffractometer with Mo-Ka radiation $(\lambda=0.71073 \AA)$. The structures were solved and refined using the Bruker SHELXTL Software Package using SHELXS-97 (Sheldrick, 2014) and refined by full matrix least-squares on F2 using SHELXL-97 (Sheldrick, 2014) with anisotropic thermal parameters for all non-hydrogen atoms [18]. The hydrogen atoms were introduced at calculated positions and not refined (riding model).

\section{5. $\left[\operatorname{Ti}\left(\mathrm{L}^{1}\right)_{2}((1 R, 2 R)\right.$-dpeda $\left.)\right]$ and $\left[\operatorname{Ti}\left(\mathrm{L}^{1}\right)_{2}((1 S, 2 S)\right.$-dpeda $\left.)\right]$}

Under an inert atmosphere, $\left[\mathrm{Ti}\left(\mathrm{L}^{1}\right)_{2}\left(\mathrm{HOPr}^{\mathrm{i}}\right)_{2}\right](10 \mathrm{mg}, 11.9 \mu \mathrm{mol})$ and the enantiopure dpeda ligand $(2.6 \mathrm{mg}, 1$ equiv) were dissolved in dry $\mathrm{CH}_{2} \mathrm{Cl}_{2}(1 \mathrm{~mL})$. The resulting mixture was ultrasonicated and crystals were obtained by slow diffusion of pentane vapours (yield $6 \mathrm{mg}, 54 \%$ ). ${ }^{1} \mathrm{H}$ RMN $\left(\mathrm{CD}_{2} \mathrm{Cl}_{2}, 600 \mathrm{MHz}\right)$ : major isomer, $\delta=7.60-6.80(\mathrm{~m}, 38 \mathrm{H})$, $5.79\left(\mathrm{~d},{ }^{3} J=7.6 \mathrm{~Hz}, 4 \mathrm{H}\right), 3.49(\mathrm{~m}, 2 \mathrm{H}), 2.81(\mathrm{~m}, 2 \mathrm{H}), 2.25(\mathrm{~m}, 2 \mathrm{H})$; minor isomer, $\delta=7.60-6.80(\mathrm{~m}, 38 \mathrm{H}), 6.26\left(\mathrm{~d},{ }^{3} \mathrm{~J}=7.4 \mathrm{~Hz}, 4 \mathrm{H}\right), 3.10$ (m, 2H), $2.57(\mathrm{~m}, 2 \mathrm{H}), 1.91(\mathrm{~m}, 2 \mathrm{H}) .{ }^{13} \mathrm{C}\left\{{ }^{1} \mathrm{H}\right\} \mathrm{NMR}\left(\mathrm{CD}_{2} \mathrm{Cl}_{2}, 125 \mathrm{MHz}\right)$ : $\delta=160.9,160.8,160.1,160.0,141.8,141.3,139.5,139.3,138.9$, $132.8,132.7,132.6,132.5,130.7,130.5,130.4,130.3,130.2,130.1$, $130.0,129.9,129.7,129.5,129.3,129.2,129.1,129.0,128.8,128.6$, $128.5,128.3,128.2,128.1,127.3,127.2,127.1,127.0,126.9,126.8$, $122.2,122.1,120.9,120.8,63.0,62.0 .{ }^{1} \mathrm{H}$ NMR DOSY $\left(\mathrm{CDCl}_{3}, 600 \mathrm{MHz}\right)$ : $\mathrm{D}=579 \pm 10 \% \mu \mathrm{m}^{2} \mathrm{~s}^{-1}$. ES-MS : $\mathrm{m} / \mathrm{z}=933.32$ calcd for $[[\mathrm{Ti}$ $\left(\mathrm{L}^{1}\right)_{2}$ (dpeda) $\left.+\mathrm{H}^{+}\right]: \quad m / z=933.32 . \quad\left[\mathrm{Ti}\left(\mathrm{L}^{1}\right)_{2}((1 R, 2 R)-(+)\right.$-dpeda $\left.)\right]$ : $[\alpha]_{\mathrm{D}}^{22}=+140^{\circ} \cdot \mathrm{dm}^{-1} \cdot \mathrm{g}^{-1} \cdot \mathrm{cm}^{3}$. Anal. Calcd. for $\mathrm{C}_{62} \mathrm{H}_{48} \mathrm{~N}_{2} \mathrm{O}_{4} \mathrm{Ti} \cdot 3 / 4 \mathrm{CH}_{2} \mathrm{Cl}_{2}$ : C, 75.62; N, 2.81; H, 5.01. Found C, 75.62; N, 2.85; H, 5.25. [Ti $\left(\mathrm{L}^{1}\right)_{2}((1 S, 2 S)-(-)$-dpeda) $]:[\alpha]_{\mathrm{D}}^{22}=-150^{\circ} \cdot \mathrm{dm}^{-1} \cdot \mathrm{g}^{-1} \cdot \mathrm{cm}^{3}$. Anal. Calcd. for $\mathrm{C}_{62} \mathrm{H}_{48} \mathrm{~N}_{2} \mathrm{O}_{4} \mathrm{Ti} \cdot 1 / 4 \mathrm{CH}_{2} \mathrm{Cl}_{2}: \mathrm{C}, 78.36 ; \mathrm{N}, 2.94 ; \mathrm{H}, 5.12$. Found C, 78.44; N, 2.72; H, 5.44 .

\section{6. $\left[\mathrm{Ti}_{2}\left(\mathrm{~L}^{2}\right)_{2}((1 R, 2 R) \text {-dpeda })_{2}\right]$ and $\left[\mathrm{Ti}_{2}\left(\mathrm{~L}^{2}\right)_{2}((1 S, 2 S) \text {-dpeda })_{2}\right]$}

Under inert atmosphere, $\mathrm{L}^{2} \mathrm{H}_{4}(16,70 \mu \mathrm{mol})$ and the enantiopure dpeda ligand $(16,70 \mu \mathrm{mol})$ were solubilized in dry degazed toluene. To this solution was added $\mathrm{Ti}\left(\mathrm{O}^{\mathrm{i}} \mathrm{Pr}\right)_{4}(5 \mu \mathrm{L})$. The resulting solution was heated at $100{ }^{\circ} \mathrm{C}$ and orange crystals appeared in the medium after two days. X-ray crystal structure CCDC for $\left[\mathrm{Ti}_{2}\left(\mathrm{~L}^{2}\right)_{2}((1 R, 2 R) \text {-dpeda })_{2}\right]$ 1916725; $\quad P 2_{1} / c ; \quad a=20.1956(11) \quad \AA, \quad b=26.3701(15) \quad \AA$, $c=21.0982(9) \AA, \alpha=90^{\circ}, \beta=102.927(2)^{\circ}, \gamma=90^{\circ}, \mathrm{Z}=4$. The final 
anisotropic full-matrix least-squares refinement on $\mathrm{F}^{2}$ with 2425 variables converged at $\mathrm{R} 1=9.57 \%$, for the observed data and $\mathrm{w} R 2=26.83 \%$ for all data. The goodness-of-fit was 1.023 . CCDC for $\left[\mathrm{Ti}_{2}\left(\mathrm{~L}^{2}\right)_{2}((1 S, 2 S) \text {-dpeda })_{2}\right]$ 1916728. ${ }^{1} \mathrm{H}$ RMN $\left(\mathrm{C}_{2} \mathrm{D}_{2} \mathrm{Cl}_{4}, 600 \mathrm{MHz}\right)$ : first isomer, $\delta=8.46(\mathrm{~s}, 4 \mathrm{H}), 8.10(\mathrm{~s}, 2 \mathrm{H}), 7.92(\mathrm{~s}, 2 \mathrm{H}), 7.71(\mathrm{~d}$, $\left.{ }^{3} J=8.0 \mathrm{~Hz}, 2 \mathrm{H}\right), 7.68\left(\mathrm{~d},{ }^{3} J=8.0 \mathrm{~Hz}, 2 \mathrm{H}\right), 7.54-6.80(\mathrm{~m}, 52 \mathrm{H}), 6.39$ (d, $\left.{ }^{3} J=7.3 \mathrm{~Hz}, 4 \mathrm{H}\right), 6.34(\mathrm{~m}, 4 \mathrm{H}), 4.07(\mathrm{~m}, 2 \mathrm{H}), 2.71(\mathrm{~m}, 2 \mathrm{H}), 2.60(\mathrm{~m}$, $4 \mathrm{H}), 2.18(\mathrm{~m}, 2 \mathrm{H}), 1.97(\mathrm{~m}, 2 \mathrm{H})$; second isomer, $\delta=8.39$ (s, 4H), 8.25 (s, 2H), 8.23 (s, 2H), $7.86\left(\mathrm{~d},{ }^{3} J=7.9 \mathrm{~Hz}, 2 \mathrm{H}\right), 7.64\left(\mathrm{~d},{ }^{3} J=8.0 \mathrm{~Hz}\right.$, $2 \mathrm{H}), \quad 7.54-6.80(\mathrm{~m}, 52 \mathrm{H}), 5.92\left(\mathrm{~d},{ }^{3} J=7.7 \mathrm{~Hz}, 4 \mathrm{H}\right), 5.75$ (d, $\left.{ }^{3} J=7.5 \mathrm{~Hz}, 4 \mathrm{H}\right), 3.92(\mathrm{~m}, 2 \mathrm{H}), 3.19(\mathrm{~m}, 4 \mathrm{H}), 2.81(\mathrm{~m}, 2 \mathrm{H}), 2.60(\mathrm{~m}$, $2 \mathrm{H}), 2.07(\mathrm{~m}, 2 \mathrm{H}) .{ }^{13} \mathrm{C}\left\{{ }^{1} \mathrm{H}\right\}$ NMR $\left(\mathrm{C}_{2} \mathrm{D}_{2} \mathrm{Cl}_{4}, 125 \mathrm{MHz}\right): \delta=161.1$, $161.0,160.8$, 160.6, 160.1, 159.9, 159.7, 159.4, 141.8, 141.5, 139.1, 139.0, 138.7, 138.3, 138.1, 137.9, 137.8, 137.7, 136.4, 133.1, 132.9, 132.6, 132.5, 132.4, 132.2, 132.0, 131.6, 131.1, 130.8, 130.8, 130.7, $130.6,130.4,130.3,130.2,130.0,129.7,129.6,129.5,129.4,129.3$, $129.1,128.9,128.8,128.7,128.5,128.1,128.0,127.8,127.7,127.6$, $127.5,127.4,127.3,127.2,126.9,126.3,125.9,125.8,125.7,125.6$, $125.4,124.8,124.1,122.4,122.2,121.0,120.9,120.7,120.6,120.0$, 63.0, 62.6, 62.4, 61.1. ${ }^{1} \mathrm{H}$ NMR DOSY $\left(\mathrm{CDCl}_{3}, 600 \mathrm{MHz}\right): D=$ $(423 \pm 10 \%) \quad \mu \mathrm{m}^{2} \mathrm{~s}^{-1}$. ES-MS: $m / z=1732.52$ calcd for $\left.\left.\left[\left[\mathrm{Ti}_{2}\left(\mathrm{~L}^{2}\right)_{2} \text { (dpeda) }\right)_{2}\right]+\mathrm{Na}^{+}\right]: \quad m / z=1732.52\right) . \quad\left[\mathrm{Ti}_{2}\left(\mathrm{~L}^{2}\right)_{2}((1 R, 2 R)-\right.$ dpeda $\left.)_{2}\right]: \quad[\alpha]_{\mathrm{D}}^{22}=440^{\circ} \cdot \mathrm{dm}^{-1} \cdot \mathrm{g}^{-1} \cdot \mathrm{cm}^{3}, \quad\left[\mathrm{Ti}_{2}\left(\mathrm{~L}^{2}\right)_{2}((1 S, 2 S) \text {-dpeda })_{2}\right]$ : $[\alpha]_{\mathrm{D}}^{22}=-450^{\circ} \cdot \mathrm{dm}^{-1} \cdot \mathrm{g}^{-1} \cdot \mathrm{cm}^{3}$. Anal. Calcd. for $\left[\mathrm{Ti}_{2}\left(\mathrm{~L}^{2}\right)_{2}((1 S, 2 S)-\right.$ dpeda) $)_{2}$ ]: $\mathrm{C}_{112} \mathrm{H}_{84} \mathrm{~N}_{4} \mathrm{O}_{8} \mathrm{Ti}_{2}$ : C, 78.68; N, 3.28; H, 4.95. Found C, 78.39; $\mathrm{N}, 3.23$; H, 5.06. Anal. Calcd. for $\left[\mathrm{Ti}_{2}\left(\mathrm{~L}^{2}\right)_{2}((1 R, 2 R) \text {-dpeda })_{2}\right]$ : $\mathrm{C}_{112} \mathrm{H}_{84} \mathrm{~N}_{4} \mathrm{O}_{8} \mathrm{Ti}_{2}$ : C, 78.68; N, 3.28; H, 4.95. Found C, 78.72; N, 3.15; H, 5.04 .

\section{Computational details}

DFT calculations were performed using the GAUSSIAN09.D01 [19] software. Optimisation of the various complexes were done using the density functional theory in combination with the wB97XD [14] long range functional and the Def2-TZVP basis set [20]. CD spectra were obtained using the sTDA-xtb method developed by S. Grimme et al.

\section{Acknowledgements}

The experimental contribution of Xavier Mosca is gratefully acknowledged. We thank the Centre National de la Recherche Scientifique (CNRS) and the University of Strasbourg (UDS) for financial support. We are extremely grateful to Dr. Jean-Claude Chambron for providing us precious advices.

\section{Appendix A. Supplementary data}

Supplementary data to this article can be found online at https:// doi.org/10.1016/j.ica.2019.119119.

\section{References}

[1] a) E. Yashima, N. Ousaka, D. Taura, K. Shimomura, T. Ikai, K. Maeda, Chem. Rev. 116 (2016) 13752-13990;

b) J. Crassous, Chem. Commun. 48 (2012) 9684-9692;

c) U. Knof, A. von Zelewsky, Angew. Chem. Int. Ed. 38 (1999) 302-322.

[2] a) L.-J. Chen, H.-B. Yang, M. Shionoya, Chem. Soc. Rev. 46 (2017) 2555-2576; b) E.C. Constable, Chem. Soc. Rev. 42 (2013) 1637-1651; c) J. Lacour, V. Hebbe-Viton, Chem. Soc. Rev. 32 (2003) 373-382.

[3] a) For general reviews on helicates see: a) M. Albrecht, Chem. Rev. 101 (2001) 3457-3498 ; b) C. Piguet, G. Bernardinelli, G. Hopfgartner, Chem. Rev. 97 (1997) 2005-2062.

[4] a) Z. Zhang, Y. Zhou, H. Li, T. Gao, P. Yan, Dalton Trans. 48 (2019) 4026-4034 For recent works on helicates see:;

b) M.-X. Yao, L.-Z. Cai, X.-W. Deng, W. Zhang, S.-J. Liu, X.-M. Cai, New J. Chem. 42 (2018) 17652-17658;

c) H. Yoo, J. Lee, P. Kang, M.-G. Choi, Dalton Trans. 44 (2015) 14213-14216; d) C.-S. Tsang, L. Chen, L.-W. Li, S.-M. Yiu, T.-C. Lau, H.-L. Kwong, Dalton Trans. 44 (2015) 13087-13092; e) S.M. McNeill, D. Preston, J.E.M. Lewis, A. Robert, K. Knerr-Rupp, D.O. Graham, J.R. Wright, G.I. Giles, J.D. Crowley, Dalton Trans. 44 (2015) 11129-11136; f) S.A. Baudron, H. Ruffin, M.W. Hosseini, Chem. Commun. 51 (2015) 5906-5909; g) Q. Teng, H. Vinh Huynh, Chem. Commun. 51 (2015) 1248-1251;

h) J. Malina, M.J. Hannon, V. Brabec, Chem. Eur. J. 21 (2015) 11189-11195; i) C. Eerdun, S. Hisanaga, J. Setsune, Chem. Eur. J. 21 (2015) 239-246; j) J.E. Beves, J.J. Danon, D.A. Leigh, J.-F. Lemonnier, I.J. Vitorica-Yrezabal, Angew. Chem., Int. Ed. 54 (2015) 7555-7559;

k) W. Cullen, C.A. Hunter, M.D. Ward, Inorg. Chem. 54 (2015) 2626-2637; 1) C.R.K. Glasson, G.V. Meehan, M. Davies, C.A. Motti, J.K. Clegg, L.F. Lindoy, Inorg. Chem. 54 (2015) 6986-6992.

[5] For a review on the synthesis of optically pure helicates see: S.E. Howson, P. Scott, Dalton Trans. 40 (2011) 10268-10277.

[6] a) A. Jarzebski, C. Tenten, C. Bannwarth, G. Schnakenburg, S. Grimme, A. Lützen, Chem. Eur. J. 23 (2017) 12380-12386;

b) S.E. Howson, A. Bolhuis, V. Brabec, G.J. Clarkson, J. Malina, A. Rodger, P. Scott, Nature Chemistry 4 (2012) 31-36;

c) J. Bunzen, T. Bruhn, G. Bringmann, A. Lützen, J. Am. Chem. Soc. 131 (2009) 3621-3630.

[7] a) D. Zhao, T. van Leeuwen, J. Cheng, B.L. Feringa, Nature Chemistry 9 (2017) 250-256;

b) C.-S. Tsang, C.-C. Yee, S.-M. Yiu, W.-T. Wong, H.-L. Kwong, Polyhedron 83 (2014) 167-177;

c) F.G. Gelalcha, M. Schulz, R. Kluge, J. Sieler, J. Chem. Soc., Dalton Trans. (2002) 2517-2521;

d) G. Baum, E.C. Constable, D. Fenske, C.E. Housecroft, T. Kulke, M. Neuburger, M. Zehnder, J. Chem. Soc., Dalton Trans. (2000) 945-959.

[8] a) For a not metallo-based system see: W. Zuo, Z. Huang, Y. Zhao, W. Xu, Z. Liu, X.J. Yang, C. Jia, B. Wu, Chem. Commun. 54 (2018) 7378 for helicates see; b) Q. Lin, L. Gao, B. Kauffmann, J. Zhang, C. Ma, D. Luoa, Q. Gan, Chem. Commun. 54 (54) (2018) 13447;

c) T. Haino, H. Shio, R. Takano, Y. Fukazawa, Chem. Commun. (2009) 2481-2483; d) R.M. Yeh, K.N. Raymond, Inorg. Chem. 45 (2006) 1130-1139;

e) J. Lacour, J.J. Jodry, D. Monchaud, Chem. Commun. (2001) 2302-2303.

[9] a) Y. Sakata, S. Chiba, M. Miyashita, T. Nabeshima, S. Akine, Chem. Eur. J. 25 (2019) 2962-2966;

b) S. Sairenji, S. Akine, T. Nabeshima, Chem. Lett. 43 (2014) 1107-1109; c) S. Sairenji, S. Akine, T. Nabeshima, Tetrahedron Lett. 55 (2014) 1987-1990; d) J. Setsune, J. Chem. Sci. 124 (2012) 1151-1163;

e) S.J. Wezenberg, G. Salassa, E.C. Escudero-Adán, J. Benet Buchholz, A.W. Kleij, Angew. Chem. Int. Ed. 50 (2011) 713-716;

f) T. Mizutani, S. Yagi, A. Honmaru, S. Murakami, M. Furusyo, T. Takagishi, H. Ogoshi, J. Org. Chem. 63 (1998) 8769-8784.

[10] S. Akine, Inorganics 80 (6) (2018) 2-19.

[11] a) N. Baradel, P. Mobian, G. Khalil, M. Henry, Dalton Trans. 46 (2017) 7594-7602; b) P. Mobian, N. Baradel, N. Kyritsakas, G. Khalil, M. Henry, Chem. Eur. J. 21 (2015) 2435-2441.

[12] a) T. Ikariya, S. Hashiguchi, K. Murata, R. Noyori, Org. Synth. 82 (2005) 10; b) S. Pikul, E.J. Corey, Org. Synth. 71 (1993) 22.

[13] D.M. Weekes, N. Baradel, N. Kyritsakas, P. Mobian, M. Henry, Eur. J. Inorg. Chem. 34 (2012) 5701-5713.

[14] J.-D. Chai, M. Head-Gordon, Phys. Chem. Chem. Phys. 10 (2008) 6615-6620.

[15] a) C. Chaumont, E. Huen, C. Huguenard, P. Mobian, M. Henry, Polyhedron 57 (2013) 70-76;

b) K. Gigant, A. Rammal, M. Henry, J. Am. Chem. Soc. 123 (2001) 11632-11637; c) P. Persson, R. Bergstrom, S. Lunell, J. Phys. Chem. B 104 (2000) 10348-10351.

[16] S. Grimme, C. Bannwarth, J. Chem. Phys. 145 (2016) 054103.

[17] C. Diebold, P. Mobian, C. Huguenard, L. Allouche, M. Henry, Dalton Trans. (2009) 10178-10180.

[18] a) G.M. Sheldrick, Acta Crystallogr. Sect. C: Cryst. Struct. Commun. 71 (2015) 3-8; b) G.M. Sheldrick, Acta Crystallogr. Sect. A: Fundam. Crystallogr. 64 (2008) $112-122$.

[19] Gaussian 09, Revision A.02, M. J. Frisch, G. W. Trucks, H. B. Schlegel, G. E. Scuseria, M. A. Robb, J. R. Cheeseman, G. Scalmani, V. Barone, G. A. Petersson, H. Nakatsuji, X. Li, M. Caricato, A. Marenich, J. Bloino, B. G. Janesko, R. Gomperts, B. Mennucci, H. P. Hratchian, J. V. Ortiz, A. F. Izmaylov, J. L. Sonnenberg, D. Williams-Young, F. Ding, F. Lipparini, F. Egidi, J. Goings, B. Peng, A. Petrone, T. Henderson, D. Ranasinghe, V. G. Zakrzewski, J. Gao, N. Rega, G. Zheng, W. Liang, M. Hada, M. Ehara, K. Toyota, R. Fukuda, J. Hasegawa, M. Ishida, T. Nakajima, Y. Honda, O. Kitao, H. Nakai, T. Vreven, K. Throssell, J. A. Montgomery, Jr., J. E. Peralta, F. Ogliaro, M. Bearpark, J. J. Heyd, E. Brothers, K. N. Kudin, V. N. Staroverov, T. Keith, R. Kobayashi, J. Normand, K. Raghavachari, A. Rendell, J. C. Burant, S. S. Iyengar, J. Tomasi, M. Cossi, J. M. Millam, M. Klene, C. Adamo, R. Cammi, J. W. Ochterski, R. L. Martin, K. Morokuma, O. Farkas, J. B. Foresman, and D. J. Fox, Gaussian, Inc., Wallingford CT, 2016. Gaussian 09, Revision A.02, M. J. Frisch, G. W. Trucks, H. B. Schlegel, G. E. Scuseria, M. A. Robb, J. R. Cheeseman, G. Scalmani, V. Barone, G. A. Petersson, H. Nakatsuji, X. Li, M. Caricato, A. Marenich, J. Bloino, B. G. Janesko, R. Gomperts, B. Mennucci, H. P. Hratchian, J. V. Ortiz, A. F. Izmaylov, J. L. Sonnenberg, D. Williams-Young, F. Ding, F. Lipparini, F. Egidi, J. Goings, B. Peng, A. Petrone, T. Henderson, D. Ranasinghe, V. G. Zakrzewski, J. Gao, N. Rega, G. Zheng, W. Liang, M. Hada, M. Ehara, K. Toyota, R. Fukuda, J. Hasegawa, M. Ishida, T. Nakajima, Y. Honda, O. Kitao, H. Nakai, T. Vreven, K. Throssell, J. A. Montgomery, Jr., J. E. Peralta, F. Ogliaro, M. Bearpark, J. J. Heyd, E. Brothers, K. N. Kudin, V. N. Staroverov, T. Keith, R. Kobayashi, J. Normand, K. Raghavachari, A. Rendell, J. C. Burant, S. S. Iyengar, J. Tomasi, M. Cossi, J. M. Millam, M. Klene, C. Adamo, R. Cammi, J. W. Ochterski, R. L. Martin, K. Morokuma, O. Farkas, J. B. Foresman, and D. J. Fox, Gaussian, Inc., Wallingford CT, (2016).

[20] F. Weigend, R. Ahlrichs, Phys. Chem. Chem. Phys. 7 (2005) 3297-3305. 